\title{
AN ANGLO-AMERICAN PRIZE TRIBUNAL
}

One of the best achievements of The Hague Conference of 1907 was the scheme for an International Court of Appeal in Prize Cases. The world was not ready for it, and the differences of view between the greater and the lesser Powers have not unnaturally prevented its ratification. But is it not, under present circumstances, possible that a shorter step in the same direction might and could be taken by some of those Powers who are most concerned in the proper disposition of prize court proceedings?

Madame de Staël declared that mankind was always advancing, but always in a spiral course. In 1915 the world, while it moved far during the preceding century or two in the direction of human brotherhood, seems to have come to a pause very close, so far as commercial intercourse between nations is concerned, to the point reached at the time of the French Revolution.

It may be worth while to recall some of the chief departures, at the end of the eighteenth and beginning of the nineteenth centuries, from what had been the accepted rules of international law as to restrictions of neutral trade.

The French Directory, in 1798, issued a decree that all ships having for their cargoes, in whole or in part, any English merchandise, should be held good prize, whoever was the proprietor of such merchandise, which should be held contraband from the single circumstance of its coming from England or any of its foreign settlements; that the harbors of France should be shut against all ships having touched in England, except in cases of distress; and that neutral sailors found on board English vessels might be put to death. President Addams in reference to

- this order officially declared that the interest and honor of the United States commanded them to repel any such "predatory warfare against the unquestionable rights of neutral commerce."

Two years afterwards Napoleon revoked it, but on November 21, 1806, proclaimed from his camp at Berlin a blockade of the British Isles, 
although it was plain that he could not make it effective. This action he professed to justify as a measure of retaliation for repeated breaches of international law on the part of Great Britain. That Power had issued an Order in Council of May 16, 1806, and made two supplementary ones of January 7 and November 11, 1807, to the effect that all ports of France and also those of her allies if, though such allies might not be at war with Great Britain, they excluded British ships, should be closed to commerce as fully "as if the same were actually blockaded, in the most strict and vigorous manner."

Denmark promptly protested and for answer was told by the British Foreign Office that "the law of nations justifies the employment against our enemies of the same arms he himself makes use of," and that "if third parties suffer from these measures, their demand for redress must be directed against that country which first violates the established usages of war and the rights of neutral States."

The British Orders in Council, like the decrees of Napoleon, set forth that they were issued under the right of retaliation or retorsion.

In 1811 , the validity of one of the series was attacked in a prize case coming before Sir William Scott (afterwards Lord Stowell). It was insisted by counsel that it was a measure which international law did not authorize. No English judge had spoken more clearly than he as to the unity and binding force of that law. ${ }^{1}$ No English judge had been more emphatic in holding that there cannot be a legal where there is no actual blockade. But when the last of this line of Orders in Council (that of April 26, 1809) came before him, in the case in question, which was one involving American interests, he supported it as an act of retaliation, though intimating that otherwise it would have been contrary to the law of nations.

A court of admiralty, he says, "has its unwritten law evidenced in the course of its decisions, and collected from the common usage of civilized States. At the same time, it is strictly true that by the constitution of this country the King in Council possesses legislative rights over this court, and has power to issue orders and instructions, which it is bound to obey and enforce, and these constitute the written law of

${ }^{1}$ The Maria, 1 C. Robinson's Reports, 340. 
this court. These two propositions, that the court is bound to administer the law of nations, and that it is bound to enforce the King's Orders in Council, are not at all inconsistent with each other, because these orders and instructions are presumed to conform themselves, under the given circumstances, to the principles of international law. They are either directory applications of those principles to the cases indicated in them-cases which with all the facts and circumstances belonging to them, and which constitute their legal character, could be but imperfectly known to the court itself; or they are positive regulations, consistent with those principles, applying to matters which require more exact and definite rules than those general principles are capable of furnishing."

The establishment of the particular Order of 1809, he continued, "was doubtless a great and signal departure from the ordinary state of the exercise of public hostility, but was justified by that extraordinary deviation from the common exercise of hostility in the conduct of an enemy. *** It is not an original, independent act of blockade, to be governed by the common rules that belong simply to that operation of law. It is in this instance a counteracting reflex measure, compelled by the act of the enemy, and as such subject to other considerations arising out of its peculiarly distinctive character. France declares that the subjects of other States should have no access to England: England on that account declared that the subjects of other States should have no access to France. So far this retaliatory blockade (if blockade it is to be called) is coextensive with the principle: neutrals are prohibited to trade with France because they are prohibited by France from trading with England. England acquires the right, which it would not otherwise possess to prohibit the intercourse, by virtue of the act of France." 2

It is obvious that this mode of treating the subject regards the legal effect of the acts of the belligerent Powers as to each other, as determining incidentally their legal effect upon neutrals.

Such a doctrine has some support in the principles of municipal law. Thus if a man, acting reasonably and without negligence, in self-defence fires a pistol at an assailant, and the ball accidentally wounds a by${ }^{2}$ The Fox, Edw. 311; Roscoe's Prize Cases, II, 61. 
stander, he cannot recover for the injury. ${ }^{3}$ But if it is to gain a place in the law of nations it must be by adjudications not proceeding solely from an official agency of one of the contending parties or of his sovereign, in a cause dependent on the official acts of that Power.

The precise question decided by Sir William Scott is likely to come up again in consequence of the orders affecting neutral commerce, issued by Germany, France, and Great Britain during the present wars.

Great Britain early announced her intention to adhere to the rules stated in the Declaration of London, except as to certain of them regarding contraband. Germany at first accepted the Declaration unreservedly, by incorporating its provisions, on September 13, 1914, into the German prize court regulations. Its later orders, as well as those of France and Great Britain, are quite inconsistent with the principles laid down at London. "War zones" and "radiuses of activity" far outside of any territorial waters have been proclaimed by each, in which neutral ships must not go, or go, if at all, at serious risk to life and property. Some American "ships are already in British prize courts. Two Dutch ships, sailing in forbidden waters, have been seized by Germany and taken into Zeebrugge in Belgium, where they would naturally come before a German military prize court. Would its jurisdiction be judged by the rule that the Supreme Court of the United States has laid down, that "neither the President nor any military officer can establish a court in a conquered country, and authorize it to decide upon the rights of the United States, or of individuals in prize cases, nor to administer the laws of nations. ${ }^{4}$

Can a belligerent reduce the rights of neutrals, as defined by international law, by a self-framed order primarily designed as an act of hostility towards the other belligerent; or was Judge Peters right, in 1794, when he declared that "no one nation has the right to dictate to the rest by its own ordinances what shall be the law of nations, the principles whereof must be founded in justice, and established by common usage and consent" ? ${ }^{5}$

${ }^{3}$ Morris v. Platt, 32 Conn. Reports, 75.

4 Jecker v. Montgomery, 13 How. (U. S.) Rep. 498, 515. Cf. The Grapeshot, 9 Wallace's Rep., 129.

${ }^{5}$ Hollingsworth $v$. The Betsey, 2 Peters' Adm. Rep. 340. 
It is probable that in the magnitude of the interests involved the prize litigation, present and to come, incident to the present wars, will surpass that of any previous time. The assumption by the United States of the position of an underwriter will add new complications.

Our government informed Germany last fall, that in any controversy which might arise over questions of contraband and other points covered by the Declaration of London, we should rest the American position on our rights under international law, as interpreted by traditional American policy up to the time when that Declaration was signed in 1909. This inevitably brought on a conflict of laws; and it is a conflict which concerns the world, for international law is the joint creation of the world.

Venezuela, in December, 1914, proposed to the Governing Board of the Pan-American Union, and that Union is now understood to be considering, the calling of a conference of all the neutral Powers, to formulate a general code defining the rights and responsibilities of neutral nations in time of war.

This project of setting some nations to frame laws for all, and to make it a matter of joint action, is hardly likely to receive much favor.

One much more feasible was suggested, in March, 1915, by Sir John Macdonell, the distinguished Professor of Comparative Law in University College, London. Referring to the latest Order in Council of Great Britain, he writes to the Nation that if it "is to be put into operation on a large scale, the proper complement to it is an Anglo-American convention by which questions arising under the new order might, along with other matters affecting American claimants in our prize courts, be referred to a joint tribunal."

Such a mode of procedure might naturally take the shape of an International Court of Appeal in Prize Cases, similar in principle to that planned by the twelfth Convention of the Hague Conference of 1907, but confined to the two nations in the world whose jurisprudence is most closely identical, and rests on institutions of most nearly the same character.

The tribunal could be composed of three members, one appointed by each Power, and one selected by them, or in case of their failure to 
agree, by lot from a list made up of an equal number of names submitted by each government.

The judicial power of the United States, no doubt, cannot be bargained away. But what is that power? It is settled that it is not exercised by the courts of our Territories. It is not exercised by our representatives in the present international Hague tribunal. Aside from this, however, the Anglo-American treaty which is here suggested could and naturally would be drawn up on the lines intimated in the reservation made by the United States in assenting to the Convention for the International Court of Appeal in Prize Cases. If a decree in admiralty is rendered which is not satisfactory to the losing party, relief can always be given without disturbing the decree, itself. He can appeal to his sovereign to urge a claim for justice through diplomatic channels. If allowed by the other sovereign, the end desired will be attained, not by a reversal of the judgment complained of, but by recognizing that judicially it does settle the respective rights of the parties, and further that it settles them in $a$ wrong way. ${ }^{6}$

The Supreme Court of the United States is the highest authority known to our Constitution and laws for the judicial settlement of the rights of the parties to a prize cause. But this has never been deemed to prevent a recourse to diplomatic methods for, in effect, reviewing its final judgments. A round dozen of them were thus examined by the British-American Claims Commission, under the Treaty of Washington, and half were pronounced inconsistent with "justice and equity." 7

The institution of an Anglo-American tribunal of the character suggested would at once remove many natural causes of diplomatic controversy between the two nations. It would also tend to the maintenance of justice in the disposition of prize causes. In the nature of things, a court of the captor ought not to have the final decision upon a question of international law affecting the rights of its sovereign. ${ }^{8}$

If such a tribunal proved to work smoothly, its decisions would win

${ }^{6}$ Gray v. U. S., 21 Court of Claims Rep. 340, 401.

${ }^{7}$ See the list given in Scott, The Hague Peace Conferences of 1899 and 1907, I, 478. See also Moore, International Law Digest, VII, 596, as to petitions to the Court of Claims.

${ }^{8}$ See Oppenheim, Int. Law, II, Section 385; Williams v. Armyhoyd, 7 Cranch's Rep. 423. 
respect throughout the world, and in so doing would tend to lessen occasions for diplomatic differences between belligerents and neutrals during these wars; and between all the Powers after the return of peace.

Is it, to venture still farther, impossible that the erection of such a larger tribunal as that proposed by the twelfth Convention of the Hague Conference of 1907 might even now receive further and fairer consideration? The need of something in the nature of an International Court of Prize Appeals was never so urgent as at this hour. In face of present conditions, there is less weight in the objections that were raised to its institution in 1907 and 1909. The Declaration of London has already, in large part, won a place among the canons of the law of nations. The twelfth Convention might be put under stricter limitations. Its machinery might be simplified. More perhaps might be yielded to the lesser Powers. The very attempt to open negotiations looking towards its amendment and adoption, might and in all probability would have an important effect in bringing these desolating wars to an earlier close. It would at once bring even the belligerents to speaking terms. It might result in a truce, pending the negotiations. If it took the shape of a diplomatic conference, this would give an opportunity for an informal exchange of opinion between the Powers participating in it, as to what terms of peace might by possibility be arranged. It would recall the attention of all to the fact that the ostensible cause of these wars was not its real cause. Suppose that Serbia should now grant all the demands in the Austro-Hungarian ultimatum, would it give any ground for hope of a general peace? On the contrary, the Serbian incident has become an almost negligible incident of a far past-far, as measured by the rapid course of political events.

A century ago the United States were the only considerable commercial Power not at war, but they were not in the number of the great Powers. In 1915, when the new British Order in Council was issued, they were again the only considerable commercial Power not at war, but now a great Power. As such we have a freedom of suggestion and weight of influence which gives us large opportunities. May not one of these lie in the direction of promoting diplomatic pourparters between some or all of the belligerents, as to the possibility of now setting up the International Prize Court of Appeal for the great Powers,--perhaps 
with some change of form, but pursuing the objects for which the scheme has been devised, and perhaps leaving the door open for the lesser Powers to adhere, one by one, if they see fit?

There is really no ground for saying that the question of the practicability of such a step was bound up with that as to the ratification of the Declaration of London, and therefore has been already considered and disposed of. It was considered and disposed of only for the time being and without the light thrown upon the subject by the wars that were so soon to come. "Circumstances change cases." As was once said by Henri Poincaré, "il n'y a plus des problèmes résolus et d'autres qui ne le sont pas: il y a seulement des problèmes plus ou moins résolus."

STMEON E. BALDWIN. 